\title{
Thiolsulfonate functionalized polystyrene resin: Preparation and application in the isolation and identification of electrophilic mutagens
}

\author{
Wu E ${ }^{1}$, Robert M. Carlson ${ }^{2}$ \\ 1. Research Center for Eco-Environmental Sciences, Chinese Academy of Sciences, Beijing 100085, China. E-mail: weiwob@gmail.com \\ 2. Department of Chemistry, University of Minnesota-Duluth, Duluth, MN 55812, USA
}

Received 1 February 2007; revised 8 May 2007; accepted 13 August 2007

\begin{abstract}
A new approach for isolation and identification of elecrtophilic mutagens from complex matrix was developed. Thiosulfonic anion was immobilized onto polystyrene beads and used as separation media. Potassium polystyryl-thiosulfonate, prepared from polystyrylsulfonyl chloride and KHS, was observed to selectively react with model electrophilic mutagens such as alkyl halides, $\alpha$-chloroketones and $\alpha$-chloroesters to produce polystyryl-thiosulfonic esters. After separation from other nonreactive organic compounds, the beads then reacted with ethanethiol to produce unsymmetrical ethyl disulfides which are easily detected by GC/MS. For one mutagenic compound, only one unsymmetrical disulfide was found to contain its structure part. Thus, the structure of the parent mutagens could be deduced from that of the unsymmetrical disulfides. The degree of functionalization of the potassium polystyryl-thiosulfonate resin was $1.11 \mathrm{mmol} / \mathrm{g}$. Its reactivity was discussed and its recycling method was reported here.
\end{abstract}

Key words: functionalized polystyrene; potassium polystyryl-thiosulfonate; unsymmetrical ethyl disulfides; electrophilic mutagens

\section{Introduction}

Toxicants, such as direct-acting mutagens, arise through normal metabolic sequences or from anthropogenic processes such as the chemical disinfection of water (Cheh et al., 1980). However, only a small percentage of these compounds have been positively identified in environmental samples due to the absence of appropriate separation methodology. Thus, the identification of reactive components of toxicological importance from complex matrices remains a significant issue in environmental chemistry and toxicology.

An evaluation of the structural characteristics of the various classes of toxic compounds indicates that the vast majority have functionality with inherent electron insufficiency. It has been the approach to develop a series of complementary electron-rich derivative agents to selectively label the reactive mutagenic electrophiles in samples to facilitate the isolation and identification. Among them, polymer supported reactive nucleophilic agents are of interest as they are anticipated to immobilize the toxic electrophiles that can be separated from complex matrices. Since Merrifield (1963) created the solid-phase peptide synthesis, a variety of polymer-supported reagents have been investigated for their different purpose (Sherrington and Hodge, 1988). In our case, the polymer supported nucleophilic agents should be reactive to immobilize the toxic electrophiles which will be then liberated from the polymer as labeled adducts after separation. Some special agents such as cross-linked polystyrene beads supported thiol (Chiu and Anderson, 1976) or sulfinic anion (Frechet et al., 1982) were reported to be prepared. They are reactive to electrophilic mutagens to generate immobilized sulfides and sulfones, respectively. Unfortunately, the sulfides and sulfones are stable and would not be easily cleaved for subsequent detection. For solving the problem, it is necessary to create a new polymeric nucleophilic agent. This report discussed the design and preparation of a new crosslinked polystyrene beads supported thiosulfonate and its application as medium in isolation and identification of electrophilic mutagens.

\section{Experimental}

\subsection{Instrument and chemicals}

The GC/MS instrument was a Hewlett Packard 57905970. NMR Spectra were taken on an Ibm/Bruker NRA $200 \mathrm{MHz}$ instrument. The GC was a Perkin Elmer F42 with FID detector (Germany) and a three foot by one-eighth inch column packed with 20\% SP 2100/0.1\% CW-1500 on Supelcoport ${ }^{\circledR}$ or as noted otherwise. IR spectra were taken with Nicolet 5ZDX instrument. BioBeads S-X2 ${ }^{\circledR}$ obtained from Bio-Rad Laboratories served as the starting polymer for synthesis: benzyl ethyl disulfide as a standard sample was prepared according to the literature (Jayasuriya and Regen, 1992) from ethyl 2-pyridyl disulfide which is synthesized from 2,2-dithiobispyridine. The intermediate and product were purified by silica-gel 
column chromatography and checked by NMR and MS. Ethyl 2-pyridyl disulfide: ${ }^{1} \mathrm{H}-\mathrm{NMR}\left(\mathrm{CDCl}_{3}\right)$ : $\delta 8.43-8.37$ (m, ${ }^{1} \mathrm{H}$, aromatic), 7.72-7.59 $\left(\mathrm{m},{ }^{2} \mathrm{H}\right.$, aromatic), 7.02-7.00 (m, ${ }^{1} \mathrm{H}$, aromatic), 2.77 (q, $\left.{ }^{2} \mathrm{H}, \mathrm{SCH}_{2} \mathrm{Me}\right), 1.29\left(\mathrm{t},{ }^{3} \mathrm{H}\right.$, $\mathrm{CH}_{3}$ ); MS (EI): $\mathrm{m} / \mathrm{z} 171\left(\mathrm{M}^{+}\right), 111$ (base peak), 78. Benzyl ethyl disulfide: ${ }^{1} \mathrm{H}-\mathrm{NMR}\left(\mathrm{CDCl}_{3}\right)$ : $87.34-7.25\left(\mathrm{~m},{ }^{5} \mathrm{H}\right.$, aromatic), 3.89 (s, ${ }^{2} \mathrm{H}, \mathrm{PhCH}_{2} \mathrm{~S}-$ ), 2.42 (q, ${ }^{2} \mathrm{H}, \mathrm{MeCH}_{2} \mathrm{~S}-$ ), $1.20\left(\mathrm{t},{ }^{3} \mathrm{H}, \mathrm{CH}_{3}\right) . \mathrm{MS}(\mathrm{EI}): \mathrm{m} / z$ 184( $\left.\mathrm{M}^{+}\right), 91$ (base peak), 77,65 .

Other organic chemicals used in this work were obtained from Aldrich Chemical Company.

\subsection{Procedure}

\subsubsection{Reaction of potassium thiotosylate with elec- trophiles}

Potassium thiotosylate $(1.0 \mathrm{mmol})$ and the electrophiles $(1.0 \mathrm{mmol})$ were combined in DMF $(2.0 \mathrm{ml})$ and stirred for $6 \mathrm{~h}$ at $60^{\circ} \mathrm{C}$. The reaction mixture was poured into water and extracted with chloroform. The extract was washed with water, dried over sodium sulfate and concentrated. The residue was dissolved in methylene chloride $(2.0 \mathrm{ml})$ and $1.0 \mathrm{mmol}$ each of thiol and triethyl amine (in 1.0 $\mathrm{ml}$ of methylene chloride) were added at $0^{\circ} \mathrm{C}$. After 30 min, the reaction mixture was washed with water, dried over anhydrous sodium sulfate and analyzed with GC/MS. Alternatively, the residue from the first step was dissolved in 7:1 DMF- $\mathrm{H}_{2} \mathrm{O}(2.0 \mathrm{ml})$ with dropwise addition of the thiol $(1.0 \mathrm{mmol})$, followed by stirring at room temperature for $2 \mathrm{~h}$. The resulted mixture was taken up in methylene chloride, washed with water, dried and concentrated.

\subsubsection{Preparation of polystyryl-sulfonyl chloride (beads 1)}

$\mathrm{S}-\mathrm{X} 2{ }^{\circledR}$ polymer beads $(2.60 \mathrm{~g})$ were stirred in chloroform $(100 \mathrm{ml})$ and chlorosulfonic acid $(20 \mathrm{ml})$ was added dropwise. The mixture was subsequently stirred over night under reflux and was then filtered. The beads were stirred for $30 \mathrm{~min}$ successively in chloroform and acetonitrile, followed by thoroughly washing with water, acetonitrile and ether, then vacuum dried to a constant weight (5.02 g). The IR spectra indicated absorption at 1170 and $1370 \mathrm{~cm}^{-1}$ characteristic of the sulfonyl chloride group (Fig.1a).

\subsubsection{Preparation of potassium polystyryl-thiosulfonate (beads 2)}

Five grams of beads 1 were suspended in $25 \mathrm{ml}$ of 2 mol/L KHS solution. The reaction mixture was kept at $55^{\circ} \mathrm{C}$ for $3 \mathrm{~h}$ with stirring. Then the beads were collected on a filter, washed with water, ethanol and ether, then vacuum dried to constant weight as $5.97 \mathrm{~g}$. The elemental analysis showed the contents are: C $38.71 \%$; $\mathrm{H} 4.67 \%$; S $19.31 \%$. The IR spectra are shown in Fig.1b. The degree of functionalization (DF, the determination method were mentioned later) of this beads 2 was $1.11 \mathrm{mmol} / \mathrm{g}$.

\subsubsection{Preparation of sodium polystyryl-thiosulfonate}

Sodium sulfide nonahydrate $(8.0 \mathrm{~g})$ and sodium hydroxide $(0.25 \mathrm{~g})$ were dissolved in water $(50 \mathrm{ml})$ in which beads $1(5.0 \mathrm{~g})$ were suspended by stirring. The mixture was maintained at $95^{\circ} \mathrm{C}$ for $72 \mathrm{~h}$. Then the beads were

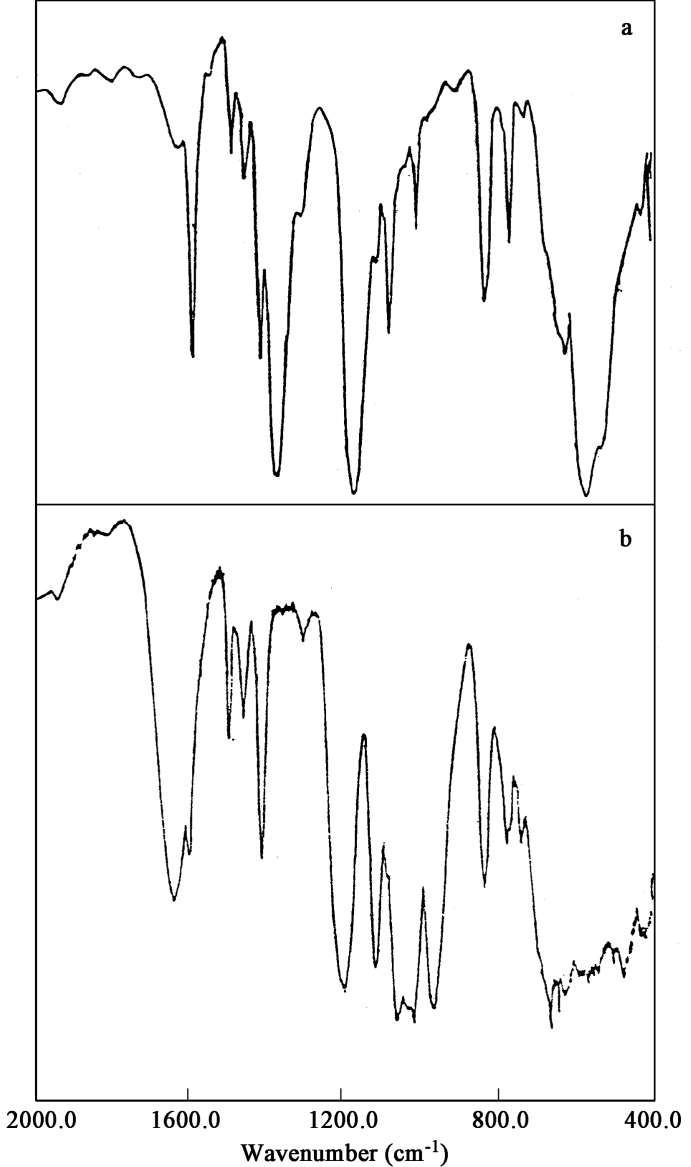

Fig. 1 IR spectra of polystyryl-sulfonyl chloride (a) and potassium polystyryl-sulfonate (b).

collected on a filter and thoroughly washed with water, ethanol and ether, dried in vacuum to a constant weight as $5.58 \mathrm{~g}$. The elemental analysis showed: $\mathrm{C} 39.23 \% ; \mathrm{H}$ $5.71 \%$; $\mathrm{S} 16.09 \%$; $\mathrm{Cl} 0.13 \%$. Its $\mathrm{DF}$ is $0.32 \mathrm{mmol} / \mathrm{g}$.

\subsubsection{Reaction of beads 2 with electrophiles and cleav- age reaction}

Single or mixed electrophiles $(0.3 \mathrm{mmol})$ were added to a slurry of beads $2(200 \mathrm{mg}$ in $1.0 \mathrm{ml}$ of $95 \%$ ethanol) and stirred at $60^{\circ} \mathrm{C}$. After $6 \mathrm{~h}$. the ethanol was removed by filtration. The beads were washed with ethanol and dried to get polystyryl-thiosulfonic esters (beads 3 ). Then the beads 3 were placed in a vial containing 2 drops of ethanethiol in $1.0 \mathrm{ml}$ of acetonitrile and allowed to react in room temperature for $12 \mathrm{~h}$. Disulfide produced were observed by direct injection of the reaction solution into the GC-MS.

\subsubsection{Detection of electrophiles in water samples via a thermostatic column packed with beads 2}

The beads $2(0.5 \mathrm{~g})$ were put inside of a small glass column which was warmed up to $60^{\circ} \mathrm{C}$ outside. Three liter of water samples containing $10-20 \mathrm{mg} / \mathrm{L}$ of single or mixed electrophiles passed through the column at a flow rate of $3 \mathrm{ml} / \mathrm{min}$ (to each $3 \mathrm{~L}$ of water sample added $5 \mathrm{ml}$ of methanol to increase the solubility of electrophiles). Then the beads were taken out to a vial and treated with $100 \mathrm{mg}$ of iodomethane for $8 \mathrm{~h}$ at room temperature. The cleavage and detection procedure is just as above mentioned. 


\subsubsection{Determination of degree of fuctionalization (DF)}

First, using standard benzyl ethyl disulfide sample to prepared the above to exactly determine the response curve of the peak area integration to the injection volume of GC. The curve is quite linear. Then the polystyryl-thiosulfonte polymer beads $(200 \mathrm{mg})$ were stirred in $2.0 \mathrm{ml}$ of $95 \%$ ethanol and $50 \mathrm{mg}$ of benzyl chloride was added to this slurry at $60^{\circ} \mathrm{C}$. After $6 \mathrm{~h}$, the ethanol was removed by filtration and the beads were washed by water and ethanol. The beads after dried were placed in a vial and $1.0 \mathrm{ml}$ of ethanol containing $50 \mathrm{mg}$ of ethanethiol was introduced. The mixture was stirred at room temperature overnight, and the solution was quantitated by peak area integration on GC. After calculation through the slope of response curve, the amount of benzyl ethyl disulfide obtained via one gram of the polystyryl-thiosulfonte beads were thought to be the degree of fuctionalization.

\subsubsection{Recycling of the used polymer}

After cleavage reaction, the polystyryl-thiosulfonic esters (beads 3 ) transferred to polystyryl-sulfinic acid (beads 4). Two grams of the used beads 4 was suspended in 50 $\mathrm{ml}$ of ethanol-water (1:1) to which $200 \mathrm{mg}$ of sulfur and $50 \mathrm{mg}$ of hexadecyltrimethyl ammonium chloride were added. The reaction mixture was kept at $90^{\circ} \mathrm{C}$ with stirring for $16 \mathrm{~h}$. After filtration, the beads were washed with water, ethanol and ether, and then dried to get $2.02 \mathrm{~g}$ of hexadecyltrimethyl ammonium polystyryl-thiosulfonate (beads 2'). The DF of the recovered beads 2' is 1.04 $\mathrm{mmol} / \mathrm{g}$.

\section{Results and discussion}

\subsection{Design and preparation of potassium polystyryl- thiosulfonate resin (beads 2)}

The need to develop effective isolation and detection methods for electrophilic mutagens directed our attention to the use of polymer to which a nucleophilic group would be covalently attached. One choice of the electro-rich derivative agents is thought to be the thiosulfonate anion because it is known that in versatile synthetic purposes the metal salts of thiosulfonic acid could react with alkyl halides to produce thiosulfonic esters in which sulfursulfur bond is able to be cleaved (Chandra and Field, 1986; Boehme and Lenz, 1984; Singh and Field, 1988; Scholz, 1984). But if the group is immobilized and these reactions are used for analysis in solid phase, it is still necessary to check whether there is any by-reaction and to see if the byproducts present interfere in the analysis or not. For this purpose, before preparing polystyryl-thiosulfonate resin, potassium thiotosylate was used as a matrix to react with electrophiles to produce toluene thiosulfonic esters:

$\mathrm{CH}_{3} \mathrm{C}_{6} \mathrm{H}_{4} \mathrm{SO}_{2} \mathrm{SK}+\mathrm{R}^{1} \mathrm{X} \longrightarrow \mathrm{CH}_{3} \mathrm{C}_{6} \mathrm{H}_{4} \mathrm{SO}_{2} \mathrm{SR}^{1}+\mathrm{KX}$

where, $\mathrm{R}^{1} \mathrm{X}$ represents electrophilic model compounds such as alkyl halides. The sulfur-sulfur bond in toluene thiosulfonic esters is able to be splitted by reducing agent to produce thiols (Kushko, 1971) or by thiols to produce disulfides (Parsons et al., 1965; Field et al., 1961, 1965). In the former case, the thiols produced readily oxidized in the air to form mixed disulfides which would cause considerable complication in the subsequent analysis. In the later case, thiols react with the thiosulfonic esters and produce unsymmetrical disulfide as main product with two symmetrical disulfides as by-products:

$$
\begin{gathered}
\mathrm{CH}_{3} \mathrm{C}_{6} \mathrm{H}_{4} \mathrm{SO}_{2} \mathrm{SR}^{1}+\mathrm{R}_{2} \mathrm{SH} \longrightarrow \mathrm{R}^{1} \mathrm{SSR}^{2}+\mathrm{R}^{1} \mathrm{SSR}^{1} \\
+\mathrm{R}^{2} \mathrm{SSR}^{2}+\mathrm{CH}_{3} \mathrm{C}_{6} \mathrm{H}_{4} \mathrm{SO}_{2} \mathrm{H} \\
\mathrm{R}^{1}, \mathrm{R}^{2}=\text { Alkyl }
\end{gathered}
$$

Obviously, the reaction mixture was not able to determine the structure of electrophilic analytes $R^{1}$ because one of them would be involved in two products or even more in complicated system. For solving this problem excess thiol $\left(\mathrm{R}^{2} \mathrm{SH}\right)$ was used to transfer the symmetrical disulfides which contain electrophilic analytes $R^{1}$ to the unsymmetrical disulfide:

$$
\mathrm{R}^{1} \mathrm{SSR}^{1}+\mathrm{R}^{2} \mathrm{SH} \text { (excess) } \longrightarrow \mathrm{R}^{1} \mathrm{SSR}^{2}
$$

The experiment proved that in this way the only measurable product containing electrophilic analytes $\mathrm{R}^{1}$ became the expected unsymmetrical disulfide $\left(\mathrm{R}^{1} \mathrm{SSR}^{2}\right)$. The other symmetrical disulfide $\left(\mathrm{R}^{2} \mathrm{SSR}^{2}\right)$ is from chosen thiol and would not interfere with the detection. Thus, the structure determination of the parent electrophiles $\left(\mathrm{R}^{1} \mathrm{X}\right)$ could be carried out through identification of the obtained unsymmetrical disulfide $\left(\mathrm{R}^{1} \mathrm{SSR}^{2}\right)$ by GC-MS or other instrument. Table 1 represents the MS data of the unsymmetrical disulfides $\left(\mathrm{R}^{1} \mathrm{SSR}^{2}\right)$ from alkyl halides $\left(\mathrm{R}^{1} \mathrm{X}\right)$ via toluene thiosulfonic esters. Fortunately, for one alkyl halide only one unsymmetrical disulfide was found in GC-MS. The results are rather encouraging.

However, as mentioned above, it is not convenient to isolate and identificate mutagenic electrophiles from complex

Table 1 MS data of disulfides produced via the reaction of organic electrophiles and potassium thiotosylate

\begin{tabular}{llll}
\hline Electrophlies ${ }^{1} \mathrm{X}$ & Cleavage reagent $\mathrm{R}^{2} \mathrm{SH}$ & Disulfides produced & EI MS m/z $(\%$, relative abundance) \\
\hline $\mathrm{C}_{2} \mathrm{H}_{5} \mathrm{I}$ & $\mathrm{HSCH}_{2} \mathrm{COOCH}_{3}$ & $\mathrm{C}_{2} \mathrm{H}_{5} \mathrm{SSCH}_{2} \mathrm{COOCH}_{3}$ & $166\left(\mathrm{M}^{+}, 60\right), 106(86), 79(58), 60(66), 45(100)$ \\
$\left(\mathrm{CH}_{3}\right)_{2} \mathrm{CHCH}_{2} \mathrm{Br}$ & $\mathrm{CH}_{3} \mathrm{CH}_{2} \mathrm{SH}$ & $\left(\mathrm{CH}_{3}\right)_{2} \mathrm{CHCH}_{2} \mathrm{SSC}_{2} \mathrm{H}_{5}$ & $150\left(\mathrm{M}^{+}, 75\right), 94(71), 57(100), 41(90)$ \\
$\mathrm{C}_{6} \mathrm{H}_{5} \mathrm{CH}_{2} \mathrm{Cl}$ & $\mathrm{HSCH}_{2} \mathrm{COOCH}$ & $\mathrm{C}_{6} \mathrm{H}_{5} \mathrm{CH}_{2} \mathrm{SSCH}_{2} \mathrm{COOCH}_{3}$ & $288\left(\mathrm{M}^{+}\right), 197,169,137,105(\mathrm{each}<10 \%), 91(100)$ \\
$\mathrm{CH}_{3} \mathrm{C}(\mathrm{O}) \mathrm{CH} \mathrm{CH}_{2} \mathrm{Cl}$ & $\mathrm{C}_{5} \mathrm{H}_{11} \mathrm{SH}$ & $\mathrm{CH}_{3} \mathrm{C}(\mathrm{O}) \mathrm{CH}_{2} \mathrm{SSC}_{5} \mathrm{H}_{11}$ & $192\left(\mathrm{M}^{+}, 14\right), 122(15), 58(14), 43(100)$ \\
$\mathrm{BrCH}_{2} \mathrm{CH}: \mathrm{CHCOOCH}_{3}$ & $\mathrm{HSCH}_{2} \mathrm{COOCH}$ & $\left(\mathrm{C}_{5} \mathrm{H}_{7} \mathrm{O}_{2}\right) \mathrm{SSCH}_{2} \mathrm{COOCH}_{3}$ & $236\left(\mathrm{M}^{+}, 15\right), 99(95), 71(100), 59(80), 45(75)$ \\
$\mathrm{ClCH}_{2} \mathrm{CN}$ & $\mathrm{C}_{5} \mathrm{H}_{11} \mathrm{SH}$ & $\left(\mathrm{CN}_{3}\right) \mathrm{CH}_{2} \mathrm{SSC}_{5} \mathrm{H}_{11}$ & $175\left(\mathrm{M}^{+}, 8\right), 71(17), 43(100), 41(36)$ \\
$\mathrm{CH}_{3} \mathrm{CH}(\mathrm{Cl}) \mathrm{COOCH}_{3}$ & $\mathrm{HSCH}_{2} \mathrm{COOCH}$ & $\mathrm{C}_{4} \mathrm{H}_{7} \mathrm{O}_{2} \mathrm{SSCH}_{2} \mathrm{COOCH}_{3}$ & $224\left(\mathrm{M}^{+}, 13\right), 192(13), 105(20), 59(100), 45(47)$ \\
$\mathrm{ClCH}_{2} \mathrm{COOCH}$ & $\mathrm{C}_{5} \mathrm{H}_{11} \mathrm{SH}$ & $\left.\mathrm{CH}_{3} \mathrm{OC}_{3} \mathrm{O}\right) \mathrm{CH}_{2} \mathrm{SSC}_{5} \mathrm{H}_{11}$ & $208\left(\mathrm{M}^{+}, 9\right), 138(9), 106(16), 71(27), 43(100)$ \\
$\mathrm{BrCH}_{2} \mathrm{CH}: \mathrm{CH}_{2}$ & $\left(\mathrm{CH}_{3}\right)_{2} \mathrm{NCH}_{2} \mathrm{CH}_{2} \mathrm{SH}$ & $\mathrm{C}_{3} \mathrm{H}_{5} \mathrm{SSC}_{4} \mathrm{H}_{10} \mathrm{~N}$ & $177\left(\mathrm{M}^{+}, 2\right), 105(5), 71(3), 58(100), 42(18)$ \\
\hline
\end{tabular}


using the small molecular nucleophilic agent like potassium thiotosylate. So our major task is to immobilize the thiosulfonic anion to polymer beads. Among the methods for preparation of functionalized polymers, the chemical modification of preformed polymers is very fruitful. Some literature (Emerson et al., 1979; Kamogawa et al,, 1983) have reported different methods for preparation of chlorosulfonyl functionalized polystyrene-divinylbenzene resins. Thus, commercially available cross-linked polystyrene beads was used to react with chlorosulfonic acid to produce polystyrylsulfonyl chloride (beads 1) which was treated with potassium hydrogen sulfide to transfer to target polymer supported potassium thiosulfonate (beads 2) just as below:

$$
\begin{gathered}
\mathrm{PS}-\mathrm{C}_{6} \mathrm{H}_{5} \stackrel{\mathrm{HSO}_{3} \mathrm{Cl}}{\longrightarrow} \mathrm{PS}-\mathrm{C}_{6} \mathrm{H}_{4} \mathrm{SO}_{2} \mathrm{Cl} \stackrel{\mathrm{KHS}}{\longrightarrow} \mathrm{PS}-\mathrm{C}_{6} \mathrm{H}_{4} \mathrm{SO}_{2} \mathrm{SK} \\
(\text { Beads 1) }
\end{gathered}
$$

PS- : cross-linked polymer skeleton

Both reaction were monitored by IR spectrum. The IR spectrum of the beads 1 (Fig.1a) indicated absorptions at 1170 and $1370 \mathrm{~cm}^{-1}$ which are characteristic of sulfonyl chloride. Then the beads 1 was treated with fresh aqueous potassium hydrogen sulfide at $55^{\circ} \mathrm{C}$. IR spectra showed it took about $3 \mathrm{~h}$ to complete the reaction. The absorptions at 1170 and $1370 \mathrm{~cm}^{-1}$ were disappeared and a new appeared absorption at $1194.5 \mathrm{~cm}^{-1}$ is characteristic of thiosulfonic group (Fig.1b). No chlorine was detected from the produced beads 2 by elemental analysis.

Generally, the capacity of a polymer resin is proportional to its DF. There are several methods of determination of the DF such as that based on weight increasing after preparation or on determination of specific element. However, because a part of the sulfonyl chloride group on beads 1 maybe hydrolyzed to sulfonic anion in the base condition during preparation of polystyryl-thiosulfonate beads 2 , so the DF of the beads 2 could not be deduced from these methods. The absence of properiate methods prompted us to search a method of direct measure of the amount of thiosulfonate group on $1 \mathrm{~g}$ of polystyrylthiosulfonate beads 2. During the research of property of the beads 2 , it is found that the reaction between beads 2 and benzyl chloride and subsequent cleavage reaction are rather specific. In other words, for these two reactions, no any by-reaction or by-product was found:

$$
\begin{gathered}
\mathrm{PS}-\mathrm{C}_{6} \mathrm{H}_{4} \mathrm{SO}_{2} \mathrm{SK}+\mathrm{C}_{6} \mathrm{H}_{5} \mathrm{Cl} \rightarrow \mathrm{PS}-\mathrm{C}_{6} \mathrm{H}_{4} \mathrm{SO}_{2} \mathrm{SC}_{6} \mathrm{H}_{5}+\mathrm{KCl} \\
(\text { Beads } 2) \\
\mathrm{PS}-\mathrm{C}_{6} \mathrm{H}_{4} \mathrm{SO}_{2} \mathrm{SC}_{6} \mathrm{H}_{5}+\text { EtSH (excess) } \rightarrow \mathrm{C}_{6} \mathrm{H}_{5} \mathrm{SSC}_{2} \mathrm{H}_{5} \\
+\left(\mathrm{C}_{2} \mathrm{H}_{5} \mathrm{~S}\right)_{2}+\mathrm{PS}-\mathrm{C}_{6} \mathrm{H}_{4} \mathrm{SO}_{2} \mathrm{H} \\
(\text { Beads } 4)
\end{gathered}
$$

According to these reactions, after removing of polystyrylsulfinic acid resin (beads 4) by filtration, benzyl ethyl disulfide would be the only compound obtained because

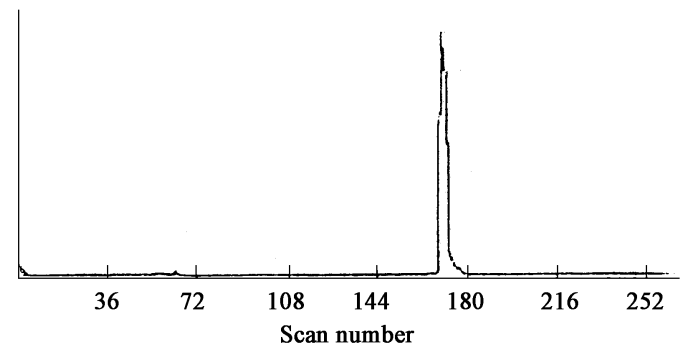

Fig. 2 TIC of benzyl ethyl disulfides produced via the reaction between the beads 2 and benzyl chloride then cleaved with ethanethiol.

diethyl disulfide is volatile and could removed together with solvent. This is confirmed by the experiment result. Fig. 2 shows the total ion chromatogram (TIC) of the products obtained via the reaction between polymer beads 2 and benzyl chloride then cleaved with ethanethiol. The only peak is assigned as benzyl ethyl disulfide and no other compound was found. The result that benzyl ethyl disulfide was the only product obtaind encourage us to consider that the DF of beads 2 could be deduced by quantitation of benzyl ethyl disulfide obtained. Thus, excess benzyl chloride was reacted with beads 2 to produce benzyl polystyryl-thiosulfonate which, after washing, was cleaved with excess ethanethiol. The obtained benzyl ethyl disulfide was quantitated by GC peak integration. Through calculation using the slope of response curve made by standard benzyl ethyl disulfide, the DF of the potassium polystyryl-thiosulfonate beads 2 was $1.11 \mathrm{mmol} / \mathrm{g}$.

Apparently, the partial hydrolysis of beads 1 under basic condition limitated the increase of efficiency of thiosulfonate formation. Other preparation methods were tried to increase the DF. For this reason, commercially available sodium sulfide was also used to react with polymer beads 1 and the reaction was monitored by IR too. After $72 \mathrm{~h}$, the IR spectrum indicated the absorption at $1195 \mathrm{~cm}^{-1}$ which was characteristic peak of the thiosulfonic group, while the peaks at 1370 and 1170 $\mathrm{cm}^{-1}$ were almost disappeared. The elemental analysis result represented that there was still very small amount of chlorine present $(0.13 \%)$. It seems that the reaction was not complete even after such a longer time. The DF of the sodium polystyryl-thiosulfonate thus obtained was only $0.32 \mathrm{mmol} / \mathrm{g}$. This indicated that because the reaction time between polystyryl-sulfonyl chloride 1 with sodium sulfide was longer than that with potassium hydrogen sulfide, the chance of hydrolysis of the sulfonyl chloride group to sulfonic group was more in the former. Further attempts to avoid hydrolysis by reacting the polymer beads 1 with sodium sulfide in nonaqueous media were unsuccessful. The use of phase transfer catalyst accelerated the reaction of polymer beads 1 with sodium sulfide, but the yield of immobilized thiosulfonate group on the beads was not enhanced beyond that observed in the aqueous process. Although the control of the hydrolysis and the maximization of the functional group content in the polymer remain goals of this work, the existence of sulfonate group in the polymer does not appear to disrupt the desired nucleophilic addition of electrophilic analytes to the thiosulfonate. By 
and large, the preparation method by the reaction of polymer beads 1 with potassium hydrogen sulfide was more efficient and convenient and could be operated with larger scale.

\subsection{Reactivity and application of potassium polystyryl- thiosulfonate resin (beads 2)}

The reactivity of the beads 2 should be the same with potassium thiotosylates. Its effectiveness was firstly tested by reacting with single excess model electrophiles such as alkyl halides, $\alpha$-chloroesters and $\alpha$-chloroketones abbreviated as RX:

$$
\begin{gathered}
\mathrm{PS}-\mathrm{C}_{6} \mathrm{H}_{4} \mathrm{SO}_{2} \mathrm{SK}+\mathrm{RX} \longrightarrow \mathrm{PS}-\mathrm{C}_{6} \mathrm{H}_{4} \mathrm{SO}_{2} \mathrm{SR}+\mathrm{KX} \\
(\text { Beads 2) } \\
(\text { Beads } 3)
\end{gathered}
$$

After removing excess electrophile by thoroughly washing, the polystyryl-thiosulfonic esters (beads 3) would be cleaved by thiol to produce disulfides as described above while the poplymer beads left became polystyryl-sulfinic acid (beads 4). For increasing volatility of resulting disulfides which is necessary when GC-MS is used, ethanethiol was chosen as cleavage agent:

$$
\begin{aligned}
& \text { PS- } \mathrm{C}_{6} \mathrm{H}_{4} \mathrm{SO}_{2} \mathrm{SR}+\mathrm{EtSH}(\text { excess }) \underset{(\text { Beads 3) }}{\longrightarrow} \mathrm{RSSC}_{2} \mathrm{H}_{5} \\
& +\left(\mathrm{C}_{2} \mathrm{H}_{5} \mathrm{~S}\right)_{2}+\underset{ }{\mathrm{PS}-\mathrm{C}_{6} \mathrm{H}_{4} \mathrm{SO}_{2} \mathrm{H}} \\
& (\text { Beads } 4)
\end{aligned}
$$

The cleavage reaction was monitored by GC. The reaction solution thus obtained was directly injected into GC-MS instrument. At room temperature the reaction took about $6-10 \mathrm{~h}$ to complete. The reaction time varied with different $\mathrm{R}$ groups. After completion of the reaction, the peak area on GC was kept unchangeable in several days. Diethyl disulfide which is oxidation product of ethanethiol has high volatility. It leaked out together with solvent and its peak would disappeared in the chart if a little bit longer solvent delay was used in the GC-MS technique. Unless there was ethyl halide in the electrophiles system, the presence of diethyl disulfide would not interfere with the subsequent detection. As mentioned above, Fig.2 shows TIC of the product obtained via the reaction between beads 2 and benzyl chloride. The only peak is assigned as benzyl ethyl disulfide and no other compound was found. For every other single electrophile, besides diethyl disulfide, also only one peak was found by GC-MS. It represents that one unsymmetrical disulfide corresponded with one original model electrophilic compound. The peak in TIC is assigned by molecular ion and their fragments in MS. The data are listed in Table 2. The results also informed that the reaction condition is so mild that all substituted groups on electrophilic compounds listed in Table 2 like hydroxyl, carbonyl, cyano etc. are maintained unchanged. Thus, the structure of the electrophilic mutagens which could react with polymer beads 2 is able to be deduced from that of the corresponding unsymmetrical disulfides.

Because the sample in environment is complex, the effectiveness of the beads 2 was also tested by reacting with mixture of model electrophiles. Fig. 3 shows the TIC of reaction products from the mixture of chloroacetonitrile, chloroacetone and 2-chloroacetophenone via the polymers. Only three unsymmetrical disulfides $\mathrm{EtSSCH}_{2} \mathrm{CN}$, $\mathrm{EtSSCH}_{2} \mathrm{C}(\mathrm{O}) \mathrm{CH}_{3}$ and $\mathrm{EtSSCH}_{2} \mathrm{C}(\mathrm{O}) \mathrm{C}_{6} \mathrm{H}_{5}$ corresponding with the three original chloro-compounds respectively

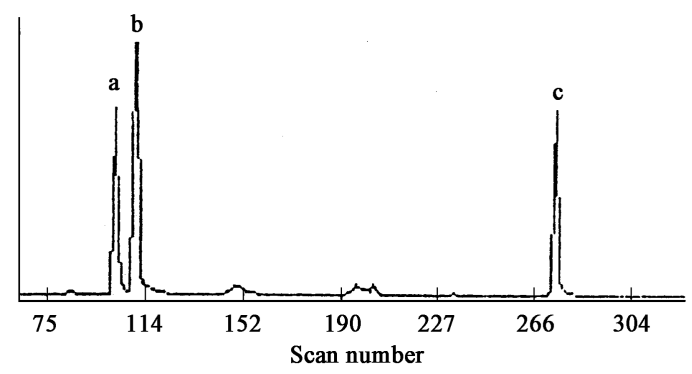

\begin{tabular}{|c|c|c|c|}
\hline Electrophiles RX & Disulfides produced & $\begin{array}{l}\text { Retention } \\
\text { time (min) }\end{array}$ & EI MS $m / z$ (\% relative abundance $)$ \\
\hline $\mathrm{CH}_{3}\left(\mathrm{CH}_{2}\right)_{2} \mathrm{Br}$ & $\mathrm{CH}_{3}\left(\mathrm{CH}_{2}\right)_{2} \mathrm{SSEt}$ & $6.10^{\mathrm{a}}$ & $136\left(\mathrm{M}^{+}, 47\right), 94(64), 79(8), 66(46), 43(100)$ \\
\hline$\left(\mathrm{CH}_{3}\right)_{2} \mathrm{CHBr}$ & $\left(\mathrm{CH}_{3}\right)_{2} \mathrm{CHSSEt}$ & $5.62^{\mathrm{a}}$ & $136\left(\mathrm{M}^{+}, 32\right), 94(100), 66(66), 43(84)$ \\
\hline $\mathrm{CH}_{3}\left(\mathrm{CH}_{2}\right)_{3} \mathrm{Br}$ & $\mathrm{CH}_{3}\left(\mathrm{CH}_{2}\right)_{3} \mathrm{SSEt}$ & $13.85^{\mathrm{b}}$ & $150\left(\mathrm{M}^{+}, 75\right), 94(100), 79(7), 66(25), 57(33)$ \\
\hline$\left(\mathrm{CH}_{3}\right)_{2} \mathrm{CHCH}_{2} \mathrm{Br}$ & $\left(\mathrm{CH}_{3}\right)_{2} \mathrm{CHCH}_{2} \mathrm{SSEt}$ & $6.73^{\mathrm{a}}$ & $150\left(\mathrm{M}^{+}, 75\right), 94(71), 79(10), 66(26), 57(100), 41(90)$ \\
\hline $\mathrm{CH}_{3}\left(\mathrm{CH}_{2}\right)_{4} \mathrm{Br}$ & $\mathrm{CH}_{3}\left(\mathrm{CH}_{2}\right)_{4} \mathrm{SSEt}$ & $8.35^{\mathrm{a}}$ & $164\left(\mathrm{M}^{+}, 17\right), 94(44), 66(10), 43(100)$ \\
\hline $\mathrm{C}_{3} \mathrm{H}_{7} \mathrm{CH}\left(\mathrm{CH}_{3}\right) \mathrm{Br}$ & $\mathrm{C}_{3} \mathrm{H}_{7} \mathrm{CH}\left(\mathrm{CH}_{3}\right) \mathrm{SSEt}$ & $7.77^{\mathrm{a}}$ & $164\left(\mathrm{M}^{+}, 15\right), 94(75), 71(14), 66(18), 43(100)$ \\
\hline $\mathrm{C}_{6} \mathrm{H}_{5} \mathrm{CH}_{2} \mathrm{Cl}$ & $\mathrm{C}_{6} \mathrm{H}_{5} \mathrm{CH}_{2} \mathrm{SSEt}$ & $11.01^{\mathrm{a}}$ & $184\left(\mathrm{M}^{+}, 10\right), 91(100), 65(17), 45(14)$ \\
\hline $\mathrm{C}_{6} \mathrm{H}_{5} \mathrm{C}(\mathrm{O}) \mathrm{CH}_{2} \mathrm{Cl}$ & $\mathrm{C}_{6} \mathrm{H}_{5} \mathrm{C}(\mathrm{O}) \mathrm{CH}_{2} \mathrm{SSEt}$ & $13.60^{\mathrm{a}}$ & $212\left(\mathrm{M}^{+}, 18.4\right), 152(7), 105(100), 77(43), 51(22)$ \\
\hline $\mathrm{CH}_{3} \mathrm{C}(\mathrm{O}) \mathrm{CH}_{2} \mathrm{Cl}$ & $\mathrm{CH}_{3} \mathrm{C}(\mathrm{O}) \mathrm{CH}_{2} \mathrm{SSEt}$ & $7.88^{\mathrm{a}}$ & $150\left(\mathrm{M}^{+}, 15\right), 107(6.5), 79(20), 43(100)$ \\
\hline $\mathrm{ClCH}_{2} \mathrm{CN}$ & $(\mathrm{CN}) \mathrm{CH}_{2} \mathrm{SSEt}$ & $7.62^{\mathrm{a}}$ & $133\left(\mathrm{M}^{+}, 40\right), 105(14), 93(20), 64(20), 45(30), 41(100)$ \\
\hline $\mathrm{CH}_{3} \mathrm{CH}(\mathrm{Cl}) \mathrm{COOCH}_{3}$ & $\mathrm{C}_{4} \mathrm{H}_{7} \mathrm{O}_{2} \mathrm{SSEt}$ & $7.85^{\mathrm{a}}$ & $180\left(\mathrm{M}^{+}, 62\right), 121(64), 93(44), 88(40), 59(100)$ \\
\hline $\mathrm{ClCH}_{2} \mathrm{COOCH}_{3}$ & $\mathrm{CH}_{3} \mathrm{OC}(\mathrm{O}) \mathrm{CH}_{2} \mathrm{SSEt}$ & $7.48^{\mathrm{a}}$ & $166\left(\mathrm{M}^{+}, 60\right), 106(100), 79(55), 60(66), 45(83)$ \\
\hline $\mathrm{ClCH}_{2} \mathrm{COOC}_{2} \mathrm{H}_{5}$ & $\mathrm{C}_{2} \mathrm{H}_{5} \mathrm{OC}(\mathrm{O}) \mathrm{CH}_{2} \mathrm{SSEt}$ & $18.12^{\mathrm{b}}$ & $180\left(\mathrm{M}^{+}, 100\right), 120(28.5), 107(36), 106(71), 93(25), 79(60), 60(50)$ \\
\hline $\mathrm{BrCH}_{2} \mathrm{CH}: \mathrm{CHCOOCH}_{3}$ & $\mathrm{CH}_{3} \mathrm{OC}(\mathrm{O}) \mathrm{CH}: \mathrm{CHCH}_{2} \mathrm{SSEt}$ & $10.06^{\mathrm{a}}$ & $192\left(\mathrm{M}^{+}, 6.5\right), 99(100), 71(36), 59(18)$ \\
\hline $\mathrm{ClCH}_{2} \mathrm{CH}_{2} \mathrm{OH}$ & $(\mathrm{OH}) \mathrm{CH}_{2} \mathrm{CH}_{2} \mathrm{SSEt}$ & $14.31^{\mathrm{b}}$ & $138\left(\mathrm{M}^{+}, 100\right), 107(7), 94(82), 79(35), 66(41), 45(48)$ \\
\hline
\end{tabular}

Fig. 3 TIC of the disulfides produced via the reaction between the beads 2 and mixture of chloroacetonitrile, chloroacetone and 2 chloroacetophenone then cleaved with ethanethiol. (a) $\mathrm{EtSSCH}_{2} \mathrm{CN}$; (b) $\mathrm{EtSSCH}_{2} \mathrm{C}(\mathrm{O}) \mathrm{CH}_{3}$; (c) $\mathrm{EtSSCH}_{2} \mathrm{C}(\mathrm{O}) \mathrm{C}_{6} \mathrm{H}_{5}$.

Table 2 GC-MS data of disulfides produced via the reaction of organic electrophiles with potassium polystyryl-thiosulfonate beads and then cleaved by ethanethiol

${ }^{\text {a }} \mathrm{GC}$ condition: $25 \mathrm{~m} \times 0.25 \mathrm{~mm} \mathrm{SE} 54$ capillary column, $50^{\circ} \mathrm{C}(1 \mathrm{~min})$ to $250^{\circ} \mathrm{C}(10 \mathrm{~min})$ at $15^{\circ} \mathrm{C} / \mathrm{min}$; ${ }^{\mathrm{b}} \mathrm{GC}$ conditions: $30 \mathrm{~m} \times 0.25 \mathrm{~mm} \mathrm{HP}-5$ capillary column, $30^{\circ} \mathrm{C}(1 \mathrm{~min})$ to $170^{\circ} \mathrm{C}(15 \mathrm{~min})$ at $6^{\circ} \mathrm{C} / \mathrm{min}$. 
were found in this experiment.

It is found that more active electrophiles such as allyl halides or benzyl chloride reacted more readily with beads 2 than alkyl halides. After beads 2 reacted with excess of equimolar mixture of methyl 4-bromocrotonate, 1-bromopentane, 2-bromopentane, 2bromopropane, 1-bromo-1-methyl-propane, benzyl chloride, methyl 2-chloropropionate and then cleaved with ethanethiol, only the disulfides derived from the more reactive benzyl chloride and methyl 4-bromocrotonate could be detected. Obviously, because the amount of beads 2 is relatively insufficient to the mixture of electrophiles, and more reactive benzyl chloride and methyl 4-bromocrotonate reacted with beads 2 much faster than other compounds, and firstly occupied all active sites on the beads 2 . In other words, only if the amount of beads 2 is sufficient, it could be possible to detect the other compounds in the electrophiles mixture. This is significant and interesting because more reactive electrophiles are more toxic to human beings, and need to be isolated and detected firstly.

The experiments result also represented that the beads 2 had apparent steric effect. When equimolar mixture of linear and branched halogenated compounds were subjected to this procedure, the peaks of the disulfides from linear compounds were observed higher than that from branched analogues. Fig. 4 shows the peak area of ethyl $n$-pentyl disulfide from 1-bromopentane through the polymer media was twelve times that of the peak from 2-bromopentane. The same phenomenon was observed in the case for methyl chloroacetate and methyl 2-chloropropionate.

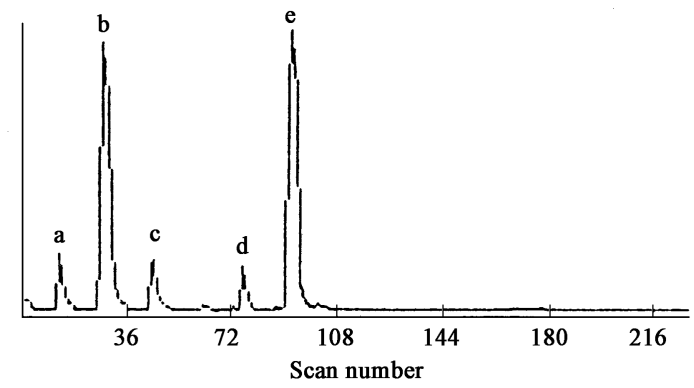

Fig. 4 TIC of the disulfides produced via the reaction between the polymer beads 2 and mixture of alkyl bromides then cleaved with ethanethiol. (a) $\mathrm{EtSSCH}\left(\mathrm{CH}_{3}\right)_{2}$; (b) $\mathrm{EtSSCH}{ }_{2} \mathrm{CH}_{2} \mathrm{CH}_{3}$; (c) $\mathrm{EtSSCH}_{2} \mathrm{CH}\left(\mathrm{CH}_{3}\right)_{2}$; (d) $\operatorname{EtSSCH}\left(\mathrm{CH}_{3}\right) \mathrm{C}_{3} \mathrm{H}_{7}$; (e) $\mathrm{EtSS}\left(\mathrm{CH}_{2}\right)_{4} \mathrm{CH}_{3}$.
As a further test, the beads 2 was packed in a column and subjected to water samples. About $0.5 \mathrm{~g}$ of the beads 2 was put inside of a small glass column which was warmed up to $60^{\circ} \mathrm{C}$ outside. $3 \mathrm{~L}$ of water samples containing $10-20 \mathrm{mg} / \mathrm{L}$ of single or mixed electrophilic model compounds passed through the column at a flow rate of $3 \mathrm{ml} / \mathrm{min}$. Then the beads were taken out to a small bottle and reacted with excess iodomethane at room temperature for $8 \mathrm{~h}$ so as to transfer all the thiosulfonate anion left in the beads to polystyryl-thiosulfonic ester group. After filtration and washing, the beads were treated with ethanethiol in acetonitrile. The reaction solution was injected to GC-MS directly. Besides methyl ethyl disulfide and diethyl disulfide, the unsymmetrical disulfides found are listed in Table 3. All samples have been detected out at this concentration level. Samples 1, 2 and 3 are single component system, just as expected, for every sample, only one peak of unsymmetrical disulfide was found, besides methyl ethyl disulfide which was leak out together with diethyl disulfide. It is interesting that for disubstituted 1,2-dichloroethane in sample 3, only bisdisulfide EtSSCH${ }_{2} \mathrm{CH}_{2} \mathrm{SSEt}$ was found. The explanation maybe is that in the dilute sample solution, when one side of 1,2-dichloroethane had been bound to the beads 2 , the other side of the molecule would be easier to react because it is nearer to the active site on beads 2 and odds of impact would be larger than that of other molecules of 1,2-dichloroethane in water solution. Sample 4 and Sample 5 are tri-component system. The effect of reactivity of the model electrophiles was also observed here. The concentrations of 2-chloroethanol in sample 4 and in sample 5 are the same, but the peak area of ethyl hydroxylethyl disulfide derived from 2-chloroethanol in sample 4 was smaller than that in sample 5. The reason is that the other two bromo-compounds $\mathrm{BrCH}_{2} \mathrm{CH}_{2} \mathrm{CH}_{3}$ and $\mathrm{Br}\left(\mathrm{CH}_{2}\right)_{3} \mathrm{CH}_{3}$ in the sample 4 are more active than the two other chlorocompounds $\mathrm{ClCH}_{2} \mathrm{COOC}_{2} \mathrm{H}_{5}$ and $\mathrm{ClCH}_{2} \mathrm{CH}_{2} \mathrm{Cl}$ present in the sample 5. The ability of competition of 2-chloroethanol in sample 4 would be lower than that in sample 5. The more reactive, the faster the electrophiles reacted with the thiosulfonate group in the polymer. The chance of reaction for compounds which are not so active must be decreased and the yield of the disulfide would be lower. Of course, the more reactive, the electrophilic mutagens are more important in toxicology, this procedure is able to selectively detect electrophilic toxicants from complex

Table 3 Detection of water samples via potassium polystyryl-thiosulfonate by GC-MS

\begin{tabular}{|c|c|c|c|c|}
\hline $\begin{array}{l}\text { Sample } \\
\text { number }\end{array}$ & $\begin{array}{l}\text { Component conc. of electro- } \\
\text { phile in water sample }(\mathrm{mg} / \mathrm{L})\end{array}$ & Disulfides detected & $\begin{array}{l}\text { Retention } \\
\text { time (min) }\end{array}$ & EI MS $(m / z)(\%$ relative abundance $)$ \\
\hline 1 & $\mathrm{ClCH}_{2} \mathrm{COOC}_{2} \mathrm{H}_{5}(10)$ & $\mathrm{EtSSCH}_{2} \mathrm{COOC}_{2} \mathrm{H}_{5}$ & $18.12^{\mathrm{b}}$ & $180\left(\mathrm{M}^{+}, 100\right), 120(28.5), 107(36), 106(71), 93(25), 79(60), 60(50)$ \\
\hline 2 & $\mathrm{ClCH}_{2} \mathrm{C}_{6} \mathrm{H}_{5}(10)$ & $\mathrm{EtSSCH}_{2} \mathrm{C}_{6} \mathrm{H}_{5}$ & $11.01^{\mathrm{a}}$ & $184\left(\mathrm{M}^{+}, 10\right), 91(100), 65(17), 45(14)$ \\
\hline 3 & $\mathrm{ClCH}_{2} \mathrm{CH}_{2} \mathrm{Cl}(20)$ & $\mathrm{EtSSCH}_{2} \mathrm{CH}_{2} \mathrm{SSEt}$ & $25.36^{\mathrm{b}}$ & $214\left(\mathrm{M}^{+}, 2.5\right), 154(12), 121(58), 93(100), 61(17), 59(23)$ \\
\hline \multirow[t]{3}{*}{4} & $\mathrm{ClCH}_{2} \mathrm{CH}_{2} \mathrm{OH}(20)$ & $\mathrm{EtSSCH}_{2} \mathrm{CH}_{2} \mathrm{OH}$ & $14.31^{\mathrm{b}}$ & $138\left(\mathrm{M}^{+}, 100\right), 107(7), 94(82), 79(35), 66(41), 45(48)$ \\
\hline & $\mathrm{BrCH}_{2} \mathrm{CH}_{2} \mathrm{CH}_{3}(20)$ & $\mathrm{EtSSCH}_{2} \mathrm{CH}_{2} \mathrm{CH}_{3}$ & $6.10^{\mathrm{a}}$ & $136\left(\mathrm{M}^{+}, 47\right), 94(64), 79(8), 66(46), 43(100)$ \\
\hline & $\mathrm{Br}\left(\mathrm{CH}_{2}\right)_{3} \mathrm{CH}_{3}(20)$ & $\mathrm{EtSS}\left(\mathrm{CH}_{2}\right)_{3} \mathrm{CH}_{3}$ & $13.85^{\mathrm{b}}$ & $150\left(\mathrm{M}^{+}, 75\right), 94(100), 79(7), 66(25), 57(33)$ \\
\hline \multirow[t]{3}{*}{5} & $\mathrm{ClCH}_{2} \mathrm{COOC}_{2} \mathrm{H}_{5}(20)$ & $\mathrm{EtSSCH}_{2} \mathrm{COOC}_{2} \mathrm{H}_{5}$ & $18.12^{\mathrm{b}}$ & $180\left(\mathrm{M}^{+}, 100\right), 120(28.5), 107(36), 106(71), 93(25), 79(60), 60(50)$ \\
\hline & $\mathrm{ClCH}_{2} \mathrm{CH}_{2} \mathrm{OH}(20)$ & $\mathrm{EtSSCH}_{2} \mathrm{CH}_{2} \mathrm{OH}$ & $14.31^{\mathrm{a}}$ & $138\left(\mathrm{M}^{+}, 100\right), 107(7), 94(82), 79(35), 66(41), 45(48)$ \\
\hline & $\mathrm{ClCH}_{2} \mathrm{CH}_{2} \mathrm{Cl}(20)$ & $\mathrm{EtSSCH}_{2} \mathrm{CH}_{2} \mathrm{SSEt}$ & $25.36^{\mathrm{b}}$ & $214\left(\mathrm{M}^{+}, 2.5\right), 154(12), 121(58), 93(100), 61(17), 59(23)$ \\
\hline
\end{tabular}

${ }^{\mathrm{a}}$ and ${ }^{\mathrm{b}}$ are the same as Table 2 . 
matrices, especially the more reactive analogs, and obtain the information about their structure.

The experiments also proved that the reaction of beads 2 with electrophiles and sulfur-sulfur bond cleavage by excess thiol are highly specific and reproducible. Other compounds present in same complex should not interfere with the detection because they had been removed by thoroughly washing prior cleavage of beads 3 .

The cleavage reaction was slower with alkyl thiols than that with aryl thiols. Generally, the reaction could be accelerated by base. For avoiding some trouble caused by base in subsequent detection it was not added here. As mentioned above the choice of ethanethiol was prompted by the need for easily detectable disulfide products by GCMS. Moreover, it is possible to select thiol for cleavage process which possesses features amenable to highly selective analytical techniques (e.g. UV absorption, fluorescent or electrochemical properties).

\subsection{Recovery of polystyryl-thiosulfonate resin}

After cleavage reaction with ethanethiol, the polymer beads left were collected and washed by water, ethanol and ether subsequently. IR spectrum indicated the polymer beads have absorptions at 1015 and $950 \mathrm{~cm}^{-1}$ which are characteristic of sulfinate group, confirming they are polystyryl-sulfinate beads (beads 4).

It was reported that sodium thiotosylate could be prepared from sodium $p$-tolunesulfinate and element sulfur under base condition (Takano et al., 1983). Theoretically, polystyryl-sulfinate beads 4 also could be recovered according to this reaction.

For the first time, the beads 4 were treated with excess sulfur in ethanol-water $(1: 1)$ containing $0.5 \%$ pyridine at $90^{\circ} \mathrm{C}$, IR spectrum indicated that it took two days to complete the reaction. After isolation and clean up, the beads reacted with propyl bromide and isobutyl bromide. After filtration and washing, the beads obtained were also cleaved by ethanethiol. The reaction mixture was checked by GC-MS. It was found that evidence of ethyl propyl trisulfide and ethyl isobutyl trisulfide were observed in GC-MS chart as well as the expected disulfides. This observation is most probably due to the presence of dithiosulfonate functionality together with thiosulfonate in the polymer beads:

$$
\text { PS- } \mathrm{C}_{6} \mathrm{H}_{4} \mathrm{SO}^{2-} \stackrel{\mathrm{S}_{8} \text {, Pyridine }}{\longrightarrow} \mathrm{PS}-\mathrm{C}_{6} \mathrm{H}_{4} \mathrm{SO}_{2} \mathrm{~S}^{-}
$$

(Beads 4)

$$
+\mathrm{PS}-\mathrm{C}_{6} \mathrm{H}_{4} \mathrm{SO}_{2} \mathrm{SS}^{-}
$$

Obviously, the trisulfides present would interrupt the detection and let the analytical results confused. For solving this problem, phase transfer catalyst hexadecyltrimthyl ammonium chloride (HTMA) was added to the reaction mixture of the beads 4 and sulfur. IR spectrum indicated that the reaction was finished after $16 \mathrm{~h}$. The beads produced were washed and dried. Its IR spectrum indicated the characteristic peaks are at 1203, 1040, 1012 and 969.5 $\mathrm{cm}^{-1}$. Besides the peak at $1012 \mathrm{~cm}^{-1}$, all other peaks have small shift comparing with the peaks at 1194.5, 1026,
1012 and $962.5 \mathrm{~cm}^{-1}$ in Fig.1b for beads 2. The shift should be attributed to the different positive ion attached to the beads. Instead of potassium polystyryl-thiosulfonate (beads 2), the recovered resin is hexadecyltrimethyl ammonium polystyryl-thiosulfonate (beads 2').

$$
\begin{gathered}
\text { PS- } \mathrm{C}_{6} \mathrm{H}_{4} \mathrm{SO}_{2} \mathrm{H} \stackrel{\mathrm{S}_{8}, \text { HTMA }}{\longrightarrow} \text { PS- } \mathrm{C}_{6} \mathrm{H}_{4} \mathrm{SO}_{2} \mathrm{~S}^{-} \mathrm{N}^{+}\left(\mathrm{CH}_{3}\right)_{3} \mathrm{C}_{16} \mathrm{H}_{33} \\
\text { (Beads 4) }
\end{gathered}
$$

Beads 2' were also subjected to propyl bromide and isobutyl bromide again and then cleaved with ethanethiol. Besides the expected disulfides, ethyl propyl disulfide and ethyl isobutyl disulfide, no trisulfides were observed by GC-MS. The DF of the recovered beads 2' was 1.04 $\mathrm{mmol} / \mathrm{g}$ determined as the method mentioned above.

\section{Conclusions}

In summary, the polystyryl-thiosulfonate beads 2 have considerable potential as media for the selective isolation and identification of reactive electrophiles from complex in environmental and biological matrices, especially the more reactive analogs, and obtain the information about their structure. It is also able to be used as sulfur donor in solid-phase synthesis of unsymmetrical disulfides or some other compounds. Finally, it is stable in storage at room temperature at least for one year.

\section{References}

Boehme H, Lenz K G, 1984. Preparation of thiosulfonic acid esters and their reactions with alcoholates or phenolates[J]. Sulfur Lett, 2(4): 151-159.

Chandra R, Field L, 1986. Organic disulfides and related substances: 46. Derivatives of 2-(benzylsulfinyl) ethanethiols[J]. J Org Chem, 51(10): 1844-1848.

Cheh A M, Stockdopole J, Heilling C et al., 1980. Water chlorination: Environmental impact and health effects (Jolley R. L., Brungs W. E., ed.)[B]. Ann Arbor, MI: Ann Arbor Science. 803-815.

Chiu S H L, Anderson L, 1976. Oligosaccharide synthesis by the thioglycoside scheme on soluble and insoluble polystyrene supports[J]. Carbohydr Res, 50(2): 227-238.

Emerson D W, Emerson R R, Joshi S C et al., 1979. Polymer-bound sulfonylhydrazene functionality: Preparation, characterization, and reactions of copoly(styrenedivinylbenzenesulfonylhydrazene)[J]. J Org Chem, 44(25): 4634-4640.

Field L, Owen T C, Crenshaw R R et al., 1961. Organic disulfides and related substances: IV. Thiolsulfonates and disulfides containing 2-aminoethyl moieties[J]. J Am Chem Soc, 83: 4414-4417.

Field L, Ferretti A, Owen T C, 1964. Organic disulfides and related substances: XI. Bisalkylidene, -alkylene, and arylene disulfides containing 2-aminoethyl moieties[J]. J Org Chem, 29(8): 2378-2382.

Frechet J M J, Hagen A J, Benezra C et al., 1982. Polymeric separation media: binding of $\alpha, \beta$-unsaturated carbonyl 
compounds to insoluble resins through Michael additions or chelation of derivatives[J]. Pure \& Appl Chem, 54(11): 2181-2188.

Jayasuriya N, Regen S L, 1992. A convenient procedure for converting organic thiols into ethyldithio derivatives[J]. Tetrahedron Lett, 33(4): 451-452.

Kamogawa H, Kanzawa A, Kadoya M et al., 1983. Conversions of carbonyl compounds via their polymeric sulfonylhydrazenes into alkenes, alkanes, and nitriles[J]. Bull Chem Soc Jpn, 56(3): 762-765.

Kushko G M, 1971. Reactions of thiosulfonic acid esters with stannous chloride[J]. Visn L'viv Politekh Inst, 58: 50-54.

Merrifield R B, 1963. Solid phase peptide synthesis: I. The synthesis of a tetrapeptide[J]. J Am Chem Soc, 85(14): 2149-2154.

Parsons T F, Buckman J D, Pearson D E et al., 1965. Organic disulfides and related substances: XIV. Aspects of the reaction of thiolsulfonates with thiols[J]. J Org Chem, 30(6): 1923-1926.

Scholz D, 1984. New synthetic methods: 9. S-Alkyl 4methylbenzenethiosulfonates, excellent reagents for $\alpha$ thiolation of cyclic ketones[J]. Liebigs Ann Chem, (2): 259-263.

Sherrington D C, Hodge P (eds.), 1988. Synthesis and separation using functional polymer[M]. London, UK: John Wiley \& Sons. 454.

Singh P K, Field L, 1988. Organic disulfides and related substances: 47. Some novel type of aminoalkyl disulfides[J]. J Chem Eng Data, 33(1): 67-68.

Takano S, Hiroya K, Ogasawara K, 1983. Facile and efficient synthesis of alkyl thiotosylates using anion exchange resin[J]. Chemistry Letters, 255-256. 